\title{
Pengaruh Orientasi Pasar terhadap Nilai Inovasi, Keunggulan Bersaing, Kinerja Unit Usaha dan Jasa Berbasis Syari'ah. (Studi Kasus unit Usaha dan Jasa berbasis Syari’ah di Wilayah Malang Raya)
}

\author{
Syahirul Alim \\ Fakultas Ekonomi UIN Maulana Malik Ibrahim Malang \\ wildanaghniya@agmail.com
}

\begin{abstract}
The marketing concept states that to achieve organizational goals such as market share and profitability depends on the company's ability to determine the needs and wants of the target market and satisfy it more effectively and efficiently than its competitors.

The purpose of this study is to examine whether pangaruh between market orientation, innovation value and competitive advantage to the performance of business units and services based on sharia. The results of statistical tests show that market orientation has a significant influence on the value of innovation. Market orientation with competitive advantage has significant influence. The value of innovation with competitive advantage has significant influence. The market orientation with the performance of shariabased business units and services has no significant effect. This study proves that the value of innovation and competitive advantage is the intervening variable to create the performance of shariah-based business units and services.
\end{abstract}

Keyword:marketing, market orientation, innovation

\section{PENDAHULUAN}

Dalam dunia bisnis, menambah jumlah pelanggan dan mempertahankannya sebagai nasabah yang loyal bisa menjadi salah satu ukuran keberhasilan perbankan. Hal ini terkait dengan efektivitas program pemasaran dan strategi yang diterapkannya. Kegiatan pemasaran tidak hanya dalam konteks transaksi antara bank dengan nasabah, lebih dari itu perusahaan juga harus menjalin hubungan yang lebih dekat dengan nasabah dengan cara lebih memahami apa harapan nasabah. Strategi pemasaran yang berorientasi pada pasar mencoba untuk membina hubungan yang lebih dekat dengan menciptakan komunikasi dua arah dengan pelanggan untuk menciptakan hubungan yang saling menguntungkan antara pelanggan dan perusahaan (Kim, 2008). Pemasaran yang berorientasi pasar merupakan aktivitas pemasaran yang memberikan perhatian pada pelanggan, pesaing dan kolaborasi unit kerja didalam perusahaan agar mengarah pada tujuan yang sama (Narver and Slater. 1990; Kohli and Jaworski. 1990). Penerapan strategi orientasi pasar menekankan pada eksplorasi kebutuhan dan harapan pelanggan dan berujung pada memberikan kepuasan pelanggan.Cakupannya meliputi tuntutan manajemen mutu terpadu untuk menghadapi dinamika kebutuhan pasar dengan lebih agresif. Tujuan lain dari orientasi pasar supaya perusahaan tetap fokus pada kegiatan menghasilkan barang atau jasa yang dibutuhkan pelanggan sehingga mengurangi resiko gagal pasar. Hal ini sesuai dengan ungkapan Narver and Slater (1990) bahwa orientasi pasar merupakan budaya organisasi yang dimanifestasikan sebagai orientasi pelanggan, orientasi pesaing, dan koordinasi antar fungsi yang ada, dengan menggunakan kriteria tujuan jangka panjang dan menghasilkan laba.

Persaingan usaha disektor keuangan yang semakin ketat menuntut para manajer untuk selalu berinovasi menciptakan produk perbankan yang menarik sebagai upaya untuk memenangkan persaingan.Dinamika faktor eksternal perlu direspon dengan inovasi untuk memenangkan persaingan (Wahyono. 2002)Lebih lanjut, Werawardena (2003) menempatkan 
inovasi sebagai salah satu variabel penting dalam menentukan kinerja.Inovasi menjadi sangat penting sebagai sarana bertahan, bukan hanya pertumbuhan dalam menghadapi ketidakpastian lingkungan dan kondisi persaingan bisnis yang semakin meningkat. Studi yang dilakukan oleh Werawardena (2003) menyimpulkan bahwa perusahaan dengan kemampuan berinovasi tinggi akan lebih berhasil dalam merespon lingkunganya dalam mengembangakan kemampuan baru yang menyebabkan keunggulan bersaing dan kinerja superior.Inovasi adalah tindakan merancang serangkaian perbedaan, mulai produk, pelayanan, citra dan personalia yang bertujuan untuk membedakan tawaran perusahaan dengan tawaran pesaing.(Kotler. 2004).Nilai inovasidiciptakan dalam wilayah dimana tindakan perusahaan secara positif memengaruhi struktur biaya dan tawaran nilai bagi pembeli (Kim. 2008).Penghematan biaya di lakukan dengan menghilangkan dan mengurangi faktor-faktor yang menjadi titik persaingan dalam industri.Nilai pembeli di tingkatkan dengan menambah dan menciptakaan elemen-elemen yang belum di tawarkan.Dalam perjalanan waktu,biaya berkurang lebih jauh ketika skala ekonomi bekerja setelah terjadi volume penjualan tinggi akibat nilai unggul yang diciptakan.

Sebagai perusahaan yang bergerak dibidang jasa, lembaga keuangan dikatakan memiliki keunggulan bersaing ketika bank tersebut mempunyai strategi tertentu yang tidak dimiliki pesaing, melakukan sesuatu lebih baik dari bank-bank lain, atau mampu melakukan sesuatu yang tidak mampu dilakukan oleh bank lain. Membangun keunggulan bersaing tersebut ditujukan untuk memberikan layanan yang superior dengan orientasi pada kepuasan pelanggan. Orientasi pada kepuasan pelanggan tersebut dalam jangka panjang akan mampu menciptakan loyalitas nasabah (Kotler and Amstrong, 2004). Dalam industri perbankan, loyalitas nasabah merupakan ukuran kinerja yang utama.

Beberapa penelitian menyatakan bahwa orientasi pasar memiliki pengaruh positif terhadap inovasi (Nasir, 2003; Kirca, 2005; Mavondo et al, 2008). Hal ini menunjukan bahwa budaya orientasi pasar dan inovasi mempunyai pengaruh untuk menciptakan keunggulan bersaing di dalam persaingan perusahaan, sehingga di perlukan inovasi total yang tidak hanya tertuju pada inovasi saja tetapi memiliki sebuah nilai, sehingga di perlukan nilai inovasi untuk menghubungkan antara orientasi pasar terhadap inovasi sehingga menciptakan keunggulan bersaing di pasar. Berdasarkan atas penjelasan tersebut, penelitian ini melakukan kajian bagaimanakah pengaruh orientasi pasar terhadap nilai inovasi, keunggulan bersaing kompetitif dan kinerja perusahaan.

Meningkatnya pertumbuhan bisnis perbankan telah mendorong kompetisi antar bank demi mengejar pertumbuhan dan mempertahankan posisi pasar.Perusahaan bersaing melalui keunggulan bersaing menciptakan diferensiasi maupun kepemimpinan biaya.Perusahaan berusaha memberikan produk bernilai tinggi kepada nasabah. Nilai inovasi adalah suatu cara untuk mengurangi intensitas persaingan, dengan kata lain keluar dari kompetisi dengan penekanan pada penyampaian produk berkualitas dengan dibarengi harga yang kompetitif. Hal ini dimaksudkan untuk menciptakan ruang pasar yang belum ada pesaingnya, fokus pada penumbuhan permintaan dan gerak menjauh dari kompetisi, dan memaksimalkan kesempatan sekaligus meminimalkan resiko sehingga menciptakan keunggulan bersaing bagi perusahaan. Pengembangan sistem perbankan syariah di Indonesia dilakukan dalam kerangka systemdual banking atau sistem perbankan ganda berdasarkan sistem Arsitektur Perbankan Indonesia(API), untuk menghadirkan alternatif jasa perbankan yang semakin lengkap kepada masyarakat Indonesia. Sistem perbankan syariah dan perbankan konvensional secara sinergis mendukung mobilisasi dana masyarakat secara lebih luas untuk meningkatkan kemampuan pembiayaan bagi sektor-sektor perekonomian nasional. Bank Syariah merupakan bank yang menjalankan kegiatan 
usahanya berdasarkan Prinsip Syariah dan menurut jenisnya terdiri atas Bank Umum Syariah dan Bank Pembiayaan Rakyat Syariah.Prinsip Syariah adalah prinsip hukum Islam dalam kegiatan perbankan berdasarkan fatwa yang dikeluarkan oleh lembaga yang memiliki kewenangan dalam penetapan fatwa di bidangsyariah (Booklet Perbankan Indonesia, 2011). Pengertian lain bank syariah atau Bank Islam adalahbank yang beroperasi dengan tidak mengandalkan pada bunga. Pada sistem operasi bank syariah,pemilik dana menanamkan uangnya di bank tidak dengan motif mendapatkan bunga, tapi dalamrangka mendapatkan keuntungan bagi hasil. Dana nasabah tersebut kemudian disalurkan kepadamereka yang membutuhkan (misalnya modal usaha), dengan perjanjian pembagian keuntungansesuai kesepakatan.Menurut sejarah perekonomian, pembiayaan yang dilakukan dengan akad syariah, telahmenjadi tradisi umat Islam sejak zaman Rasulullah SAW.Di antaranya praktik menerimapenitipan harta, meminjamkan uang untuk keperluan bisnis, serta melakukan pengiriman uang.Bank syariah adalah lembaga keuangan yang usaha produknya memberikan kredit dan jasa-jasalain dalam lalu lintas pembayaran serta peredaran uang yang beroperasi disesuaikan denganprinsip-prinsip syariah. Oleh karena itu, usaha bank akan selalu berkaitan dengan masalah uangsebagai dagangan usahanya.

Dalam UU No. 21 Tahun 2008 Tentang Perbankan Syariah pada pasal 4 dinyatakan, bahwa selain berkewajiban menjalankan fungsi menghimpun dan menyalurkan dana masyarakat,Bank Syariah dan UUS dapat menjalankan fungsi sosial dalam bentuk lembaga baitul mal, yaitumenerima dana yang berasal dari zakat, infak, sedekah, hibah, atau dana sosial lainnya danmenyalurkannya pada organisasi pengelola zakat. Selain itu Bank Syariah dan UUS juga dapat menghimpun dana sosial yang berasal dari wakaf uang dan menyalurkannya kepada pengelola wakaf (nazhir) sesuai dengan kehendak pemberi wakaf (wakif). Menurut Rizal (2009) dalam Virgowati (2013) menjelaskan bahwa dalam beberapa literatur perbankan syariah, bank syariah dengan beragam skema transaksi yang dimiliki dalam skema non-riba memiliki setidaknya empat fungsi, yaitu : (1) Manajer Investasi, dalam fungsi ini bank syariah bertindak sebagai manajer investasi dari pemilik dana (shahibul maal) dalam hal dana tersebut harus dapat disalurkan pada penyaluran yang produktif, sehingga dana yang dihimpun dapat menghasilkan keuntungan yang akan dibagi hasilkan antara bank syariah dan pemilik dana; (2) Investor, penanaman dana yang dilakukan oleh bank syariah harus dilakukan pada sektor-sektor yang produktif dengan risiko yang minim dan tidak melanggar ketentuan syariah; (3) Sosial, ada dua instrumen yang digunakan oleh bank syariah dalam menjalankan fungsi sosialnya, yaitu instrumen Zakat, Infak, Sadaqah, dan Wakaf (ZISWAF) dan instrument qardhul hasan; (4) Jasa Keuangan, fungsi jasa keuangan yang dijalankan oleh bank syariah tidaklah berbeda dengan bank konvensional, seperti memberikan layanan kliring, transfer, inkaso, pembayaran gaji, letter of guarantee, letter of credit, dan lain sebagainya. Antonio (2001) dalam Virgowati (2013), menurutnya bank syariah selain memiliki fungsi sebagai pengelola investasi dan penyedia jasajasa keuangan juga memiliki jasa sosial. Dalam pandangannya, konsep perbankan Islam mengharuskan bank syariah melaksanakan jasa sosial, bisa melalui dana pinjaman kebaikan (qard), zakat, atau dana sosial yang sesuai dengan ajaran Islam. Lebih jauh lagi menurutnya, konsep perbankan Islam juga mengharuskan bank Islam memainkan peran dalam pengembangan sumber daya insani dan meyumbang dana bagi pemeliharaan serta pengembangan lingkungan hidup. 


\subsection{Rumusan Masalah}

2. Bagaimana pengaruh signifikan orientasi pasar terhadap nilai inovasi?

3. Bagaimana pengaruh signifikan orientasi pasarterhadap keunggulan bersaing?

4. Bagaimana pengaruh signifikan orientasi pasar terhadap kinerja unit usaha dan jasa berbasis syari'ah?

5. Bagaimana pengaruh signifikan nilai inovasi terhadap keunggulan bersaing?

6. Bagaimana pengaruh signifikan nilai inovasiterhadap kinerja unit usaha dan jasa berbasis syari'ah?

7. Bagaimana pengaruh signifikan keunggulan bersaing terhadap kinerja unit usaha dan jasa berbasis syari'ah?

\subsection{Tujuan Penelitian}

1. Untuk mengetahui besarnya pengaruh orientasi pasar terhadap nilai inovasi

2. Untuk mengetahui besarnya pengaruh orientasi pasarterhadap keunggulan bersaing

3. Untuk mengetahui besarnya pengaruh orientasi pasar terhadap kinerja unit usaha dan jasa berbasis syari'ah

4. Untuk mengetahui besarnya pengaruh nilai inovasi terhadap keunggulan bersaing

5. Untuk mengetahui besarnya pengaruh nilai inovasiterhadap kinerja unit usaha dan jasa berbasis syari'ah

6. Untuk mengetahui besarnya pengaruhkeunggulan bersaing terhadap kinerja unit usaha dan jasa berbasis syari'ah

\section{KAJIAN PUSTAKA}

\subsection{Penelitian Terdahulu}

Untuk menambah wawasan keilmuan serta memperdalam literasi keilmuan yang serupa, maka peneliti perlu mengkaji bebeberapa penelitian yang terdahulu untuk sebagai bahan rujukan memperkuat dasar pemikiran penelitian selanjutnya. Penelitian tersebut diantaranya adalah sebagi berikut:

1. Pemberdayaan UMKM (Usaha Mikro, Kecil dan Menengah) Melalui Pembiayaan Dengan Prinsip bagi Hasil Oleh Lembaga Keuangan Syari'ah yang ditulis oleh Rizki Tri Anugrah Bhakti dari Universitas Putra Batam - Batam pada tahun 2014. Dalam penelitian tersebut adalah Pemberdayaan UMKM melalui pembiayaan dengan prinsip bagi hasil oleh lembaga keuangan syariah di Kota Malang masih terbentur pada risiko yang harus dihadapi. Risiko tersebut berkaitan dengan kesulitan bank sebagai shahibul maalmendapatkan informasi yang akurat mengenai karakter nasabah pengelola (mudharib) dan mengenai usaha yang akan dibiayai pada saat menyeleksi mudharibdan usahanya tersebut. Oleh sebab itu untuk meminimalisir risiko yang ada,bank menerapkan pola executing, yaitu melakukan pembiayaan mudharabahtidak secara langsung kepada UMKMmelainkan memberikan pembiayaan tersebut kepada koperasi primer serta Baitul 
Maal wat Tamwil(BMT). Pemberdayaan usaha mikro kecil dan menengah (UMKM) oleh lembaga keuangan syariah di Kota Malang terkendala oleh beberapa hal, misalnya berkaitan dengan prinsip kehati-hatian perbankan sebagaimana yang diamanatkan oleh undang-undang yaitu usaha yang tidak memiliki agunan maka dianggap tidak layak untuk mendapatkan pembiayaan. Kekhawatiran terjadinyaasymmetric information yaitu pelaporan jumlah keuntungan yang tidak benar oleh mudharibjuga menyebabkan bank sangat berhati-hati dalam memberikan pembiayaan dengan prinsip bagi hasil dalam jumlah yang banyak dan cenderung memberikan pembiayaan dengan prinsip yang lain yaitu jual belikarena dianggap lebih aman. Hal tersebut berkaitan juga dengan keterbatasan Sumber Daya Insani yang dimiliki oleh perbankan syariah. Usaha yang dijalankan olehmudharibmembutuhkan pengawasan oleh mereka yang berkompeten dibidangnya, dan pengawasan inilahyang bisa meminimalisir terjadinyaasymmetric information antarashahibul maaldengan mudharib.

2. Pengaruh Orientasi Pasar terhadap Nilai Inovasi, Keunggulan Bersaing dan Kinerja Perusahaan yang ditulis oleh Hanif Mauludin dari STIE Malang Kucecwara pada tahun 2014. Dalam penelitian tersebutadalah untuk menguji apakah pangaruh antara orientasi pasar, nilai inovasi dan keunggulan bersaing terhadap kinerja perusahaan.Hasil pengujian secara statistik menunjukkan bahwa orientasi pasar mempunyai pengaruh signifikan terhadap nilai inovasi.Orientasi pasar dengan Keunggulan bersaing mempunyai pengaruh signifikan.Nilai inovasidengan keunggulan bersaing mempunyai pengaruh signifikan.Orientasi pasar dengan kinerja perusahaan tidak mempunyai pengaruh signifikan.Penelitian ini membuktikan bahwa nilai inovasi dan keunggulan bersaing merupakan variabel intervening untuk menciptakan kinerja perusahaan.

3. Keputusan Nasabah Dalam Mengambil Produk Pembiayaan Pada Bank Syariah (Studi Kasus Pada Bank Syariah X Cabang Malang) Dwi Arida Harja A.S Fakultas Ekonomi dan Bisnis Universitas Brawijaya pada tahun 2016. Dalam penelitian ini Berdasarkan hasil penelitian kualitatif dengan teknik observasi, wawancara dan dokumentasi yang dilakukan pada nasabah dan Bank Syariah X Cabang Kota Malang tentang keputusan nasabah dalam mengambil produk pembiayaan, dapat diambil beberapa kesimpulan.Kesimpulan tersebut dipaparkan sebagai berikut:

a. Sesuai dengan informasi dan data pendukung yang diperoleh peneliti, keputusan nasabahdalam mengambil produk pembiayaan pada Bank Syariah X Cabang Kota Malang secaraumum berdasarkan pada tiga aspek yaitu sistem dan syarat-syarat pembiayaan, profit sharing, dan prosedur dan pelayanan. Selain ketiga aspek tersebut, dalam mengambil keputusan nasabah juga mempertimbangkan tingkat pencairan dana pembiayaan yang tinggi.

b. Bank Syariah X Cabang Kota Malang melakukan pendekatan kekeluargaan kepadanasabah yang akan mengambil pembiayaan. Penilaian 5C, 5P dan 3R tidak menjadipedoman utama tim marketing dalam menilai nasabah tetapi lebih kepada referral danitikad baik nasabah yang dapat dilihat pada saat proses pendekatan.

c. Profit sharing merupakan aspek yang menjadi perhatian utama nasabah sebelummemutuskan apakah akan mengambil pembiayaan pada Bank Syariah X Cabang KotaMalang atau tidak.

d. Dilihat dari sisi perbankan syariah, yang terjadi pada Bank Syariah X Cabang KotaMalang, pembiayaan konsumtif lebih tinggi pengajuannya daripada jenis pembiayaanproduktif. 


\subsection{Kajian Teori}

\subsubsection{Tinjauan tentang Pemasaran Relational}

Menurut Kotler (2004), pemasaran adalah suatu proses sosial dan manajerial dimana individu dan kelompok mendapatkan kebutuhan dan keinginan mereka dengan menciptakan, menawarkan, dan bertukar sesuatu yang bernilai satu sama lain. Dengan demikian maka dapatlah dikatakan bahwa segala tindakan yang berhubungan dengan kebijakan harga, kebijakan distribusi, kegiatan promosi, dan kegiatan menjual produk dan jasa padakonsumen yang merupakan elemen dalam pemasaran.Kotler (2004) menyatakan bahwa kunci untuk mencapai tujuan organisasi adalah penentuan kebutuhan dan keinginan pasar sasaran dan pada pemberian keputusan yang diinginkan dengan lebih efektif dari pada pesaing.Dengan demikian konsep pemasaran mencangkup pola dasar yang berorientasi pada pelanggang.Pemasaran relational merupakan suatu strategi yang menjalin hubungan jangka panjang dengan nasabah berdasarkan loyalitas yang terbentuk berdasarkan pemenuhan kebutuhan nasabah.Pergeseran paradigma pemasaran dari transaksional ke relasional telah membentuk suatu konsep baru bagi manajemen pemasaran bank.Bank harus mempersiapkan diri dengan mengarahkan visi dan misi kearah mana kecenderungan pasar dan menentukan strategi pemasaran secara tepat untuk mempertahankan kelangsungan hidup, berkembang dan mendapatkan profit jangka panjang.Atas dasar inilah perusahaan perlu mengembangkan budaya orientasi pasar yang bisa menciptakan kemampuan berinovasi tanpa henti sebagai keunggulan bersaing.

\subsubsection{Tinjauan tentang Orientasi Pasar}

Konsep pemasaran menyatakan bahwa untuk mencapai tujuan organisasi seperti market share dan profitabilitas tergantung pada kemampuan perusahaan dalam menentukan kebutuhan dan keinginan pasar sasaran dan memuaskannya dengan lebih efektif dan efisien dibandingkan dengan pesaingnya (Mavondo. 2008). Beberapa tahun terakhir orientasi pasar mengalami peningkatan dan dipandang sebagai elemen kunci untuk mencapai kinerja perusahaan. Orientasi pasar sangat penting dalam manajemen pemasaran modern (Narver dan Slater, 1990).Perusahaan yang berorientasi pasar dinilai memiliki pengetahuan tentang pasar yang lebih tinggi serta memiliki kemampuan berhubungan dengan nasabah lebih baik, kemampuan ini dipandang mampu menjamin perusahaan untuk memperoleh keuntungan yang lebih tinggi dibandingkan dengan perusahaan yang kurang berorientasi pasar (Kirca. 2005). Orientasi pasar sebagai budaya organisasi yang paling efektif dalam menciptakan perilaku penting untuk menciptakan nilai unggul bagi pembeli serta kinerja dalam bisnis. Sedangkan Uncles (2000) mengartikan orientasi pasar sebagai suatu proses dan aktivitas yang berhubungan dengan penciptaan dan pemuasan pelanggan dengan cara terus menilai kebutuhan dan keinginan pelanggan. Orientasi pasar adalah istilah untuk menggambarkan implementasi konsep pemasaran.Konsep orientasi pasar adalah dimana pendekatannya ditujukan kepada pelanggan (Hunt. 1995).Narver and Slater (1995) menyatakan bahwa orientasi pasar terdiri dari 3 komponen perilaku yaitu orientasi pelanggan, orientasi pesaing dan koordinasi interfungsional.Orientasi pelanggan dan orientasi pesaing termasuk semua aktivitasnya dilibatkan dalam memperoleh informasi tentang pembeli dan pesaing pada pasar yang dituju dan menyebarkan melalui bisnis, sedangkan koordinasi interfungsi didasarkan pada informasi pelanggan atau nasabah serta pesaing yang terdiri dari 
usaha bisnis yang terkoordinasi.Lebih jauh dijelaskan bahwa orientasi pelanggan diartikan sebagai pemahaman yang memadai tentang target beli pelanggan dengan tujuan agar dapat menciptakan nilai unggul bagi pembeli secara terus menerus. Pemahaman disini mencakup pemahaman terhadap seluruh rantai nilai pembeli, baik pada saat terkini maupun pada saat perkembanganya di masa yang akan datang. Upaya ini dapat dicapai melalui proses pencari informasi tentang nasabah (Uncles, 2000).

Orientasi pasar sangat efektif dalam mendapatkan dan mempertahankan keunggulan bersaing, yang dimulai dengan perencanaan dan koordinasi dengan semua bagian yang ada dalam organisasi untuk memuaskan kebutuhan dan keinginan nasabah. Oleh karena itu orientasi pasar harus menekankan pentingnya analisis kebutuhan dan keinginan target pasar secara lebih efisien dan efektif dibandingkan dengan pesaingnya dalam usaha untuk mencapai keunggulan bersaing. Penekanan orientasi pasar terhadap daya saing berdasarkan pada pengidentifikasian kebutuhan nasabah sehingga setiap bank dituntut untuk dapat menjawab kebutuhan yang diinginkan nasabah baik itu melalui penciptaan produk yang baru atau pengembangan dari produk yang sudah ada, agar dapat menciptakan superior value bagi konsumennya secara berkelanjutan dan dapat menjadi modal utama bagi perusahaan dan bank untuk dapat memenangkan persaingan. Orientasi pasar yang merupakan budaya bank yang menempatkan pasar sebagai kunci kelangsungan hidup bank.Oleh karenanya dalam rangka mempertahankan tingkat pertumbuhan bank di tengah persaingan yang semakin kompleks, pasar harus dikelola dengan upaya-upaya yang sistematis, dengan cara menggali informasi dan mengenali kebutuhan nasabah sehingga produk yang dihasilkan memberikan kepuasan bagi nasabah.Disamping itu pasar harus didekati dengan cara menggali informasi mengenai karakteristik dan latar belakang nasabah sehingga antisipasi terhadap pasar dapat dilakukan dengan cara proporsional.Utamanya pasar harus dilayani dengan baik bila bank secara menyeluruh bersifat responsif terhadap tuntuntan pelanggan dan pesaing dalam pasar. Dengan demikian dengan berorientasi pada pasar akan mewujudkan keunggulan bersaing bank di tengah-tengah persaingan.

\subsubsection{Tinjauan Kinerja Unit Usaha dan Jasa Berbasis Syari’ah}

Pasal 1 angka 1 Undang-Undang Nomor 21 Tahun 2008 menyebutkan Perbankan Syariah adalah segala sesuatu yang menyangkut tentang Bank Syariah dan Unit Usaha Syariah (UUS),mencakup kelembagaan, kegiatan usaha, serta cara dan proses dalam melaksanakan kegiatanusahanya. Selanjutnya dalam Pasal 1 angka 7 disebutkan Bank Syariah adalah Bank yangmenjalankan kegiatan usahanya berdasarkan prinsip syariah dan menurut jenisnya terdiri atas BankUmum Syariah dan Bank Pembiayaan Rakyat Syariah. Pasal 1 butir 8 dan 9 memberikanpenjelasan tentang dua komponen tersebut.Bank Umum Syariah adalah Bank Syariah yang dalamkegiatannya memberikan jasa dalam lalu lintas pembayaran, sedangkan Bank Pembiayaan RakyatSyariah adalah Bank Syariah yang dalam kegiatannya tidak memberikan jasa dalam lalu lintaspembayaran.Akad (ikatan, keputusan, atau penguatan) atau perjanjian atau kesepakatan atau transaksidapat diartikan sebagai komitmen yang terbingkai dengan nilai-nilai Syariah. Dalam istilah Fiqih,secara umum akad berarti sesuatu yang menjadi tekad seseorang untuk melaksanakan, baik yangmuncul dari satu pihak, seperti wakaf, talak, dan sumpah, maupun yang muncul dari dua pihak,seperti jual beli, sewa, wakalah, dan gadai. Secara khusus akad berarti keterkaitan antara ijab(pernyataan penawaran/pemindahan kepemilikan) dan qabul (pernyataan penerimaan kepemilikan)dalam lingkup yang disyariatkan dan berpengaruh pada sesuatu (Santoso, 2003). 
Untuk produk-produk pembiayaan bank syariah ditujukan untuk menyalurkan investasidan simpanan masyarakat ke sektor riil untuk tujuan produktif dalam bentuk investasi bersama(investment financing) yang dilakukan bersama mitra usaha (kreditor) menggunakan pola bagihasil (mudharabah dan musyarakah) dan dalam bentuk investasi sendiri (trade financing) kepadayang membutuhkan pembiayaan menggunakan pola jual beli (murabahah, salam, dan istishna)dan pola sewa (ijarah dan ijarah muntahiya bittamlik). Pembiayaan berdasarkan prinsip syariah sendiri adalah penyediaan uang atau tagihanyang dipersamakan, dengan itu berdasarkan persetujuan atau kesepakatan antara bank denganpihak lain yang mewajibkan pihak yang dibiayai untuk mengembalikan uang atau tagihan tersebutsetelah jangka waktu tertentu dengan imbalan atau bagi hasil, dengan sumber dari penyaluranpembiayaan ini adalah dari penghimpunan dana yang diberikan oleh nasabah atau deposan(shahibul maal).Pembiayaan dengan prinsip jual beli yang umum dan sering dijalankan di PerbankanSyariah dinamakan Murabahah.Murabahah sendiri terdiri dari beberapa skim, yaitu Cost PlusMargin, Installment Sale, As Salam, serta jual beli dengan pesanan (Al Istishna'). Untuk Cost PlusMargin merupakan jual beli dengan pembayaran sekaligus secara tunai atau waktu tenggangtertentu sesuai kesepakatan. Bai Bitsaman Ajil atau Installment Sale adalah jual beli denganpembayaran yang dilakukan secara angsuran sesuai kesepakatan.Harga jual adalah harga pokokditambah margin adalah jumlah angsuran, maka sepanjang perjanjian angsuran tersebut tidakberubah.

\subsubsection{Kaitan antara orientasi pasar terhadap nilai inovasi, keunggulan bersaing terhadap kinerja unit usaha dan jasa berbasis syari'ah.}

Sebagaimana yang telah dijelaskan bahwa keunggulan bersaing merupakan kunci untuk menghadapi persaingan yang ada.Berbagai penelitianseperti Wahyono.(2002); Werawardena (2003); Nasir (2003); Kirca (2005) menunjukkan ada dua faktor penting yang mendukung terbentuknya keunggulan bersaing yaitu orientasi pasar, dan nilai inovasi.Selain itu, penciptaan keunggulan bersaing dipandang memiliki dampak positif bagi peningkatan kinerja perusahaan.Hubungan yang terjadi antara orientasi pasar, nilai inovasi, keunggulan bersaing, dan kinerja pemasaran unit usaha dan jasa berbasis syariah tersebut selanjutnya akan disajikan secara ringkas dalam model pemikiran teoritis berikut ini:

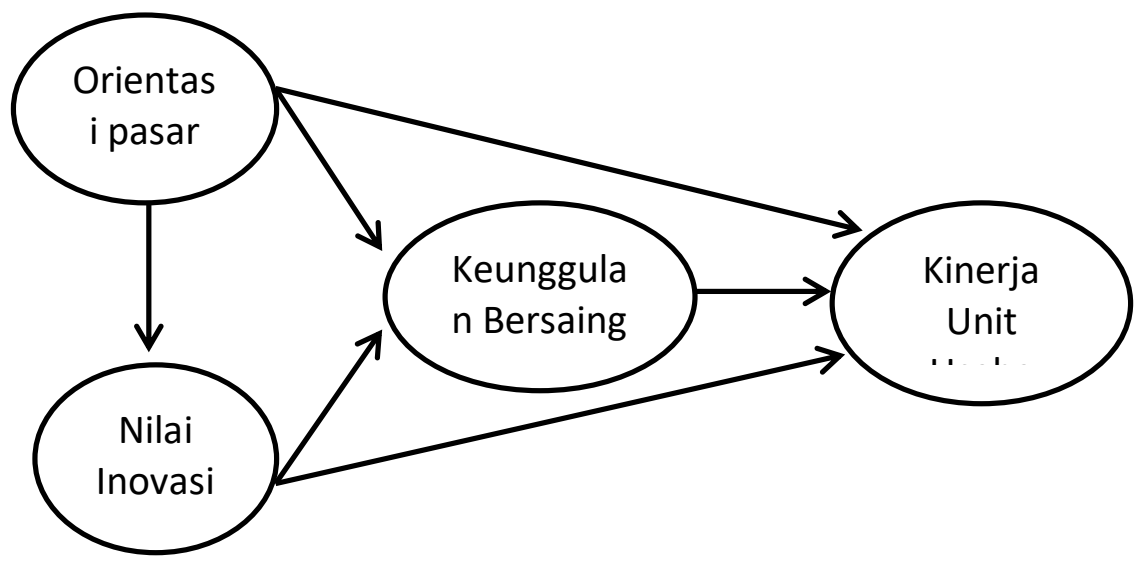

Gambar 1. Model Penelitian 


\subsection{Lokasi / Subyek Penelitian}

Untuk menentukan lokasi penelitian, maka perlu ada batasan-batasan wilayah yaitu: wilayah Malang Raya yang meliputi wilayah Malang Kota, Kabupaten Malang dan Kota Administratif Batu. Sedangkan subyek penelitian yang menjadi fokus penelitian adalah unit usaha dan jasa berbasis syariah, misalnya: hotel syari'ah, guest house syari'ah, karaoke syari'ah, laundry syari'ah, massage (pijat) syari'ah, BMT (Baitul Mal wa Tanwil), Lembaga Keuangan Mikro berbasis syari'ah, Toko/Perniagaan (Jual Beli) yang berbasis syari'ah.

\subsection{Pendekatan dan Jenis Penelitian}

Penelitian ini menggunakan jenis penelitian explanatoryyang menyoroti hubungan antara peubah-peubah penelitian dan pengujian hipotesis yang telah dirumuskan sebelumnya, Oleh karena itu dinamakan juga penelitian pengujian hipotesis.Penelitian Eksplanatori adalah penelitian bertujuan untuk menguji suatu teori atau hipotesis guna memperkuat atau bahkan menolak teori atau hipotesis hasil penelitian yang sudah ada sebelumnya.Penelitian ini ingin menguji pengaruh orientasi pasar terhadap nilai inovasi, keunggulan bersaing dan kinerja unit usaha dan jasa berbasis syari'ah.

\subsection{Populasi dan Sampel}

Sampel dalam penelitian ini perusahaan yang bergerak dibidang jasa unit usaha dan jasa berbasis syariah, misalnya: hotel syari'ah, guest house syari'ah, karaoke syari'ah, laundry syari'ah, massage (pijat) syari'ah, BMT (Baitul Mal wa Tanwil), Lembaga Keuangan Mikro berbasis syari'ah, Toko/Perniagaan (Jual Beli) yang berbasis syari'ah. .Teknik pengambilan sampel yang digunakan dalam penelitian ini yaitu purposive sampling.Purprosive sampling adalah teknik sampling yang digunakan peneliti jika peneliti mempunyai pertimbanganpertimbangan tertentu disesuaikan dengan kebutuhan penelitian.Kriteria sampel penelitian meliputi, unit usaha dan jasa yang berbasis syari'ah. yang mempunyai masa beroperasi lebih lebih dari 1 tahun.Dari hasil pendataan diperoleh sebanyak 60 unit usaha dan jasa yang tersebar diwilayah Malang raya yang sesuai dengan kriteria sampel penelitian.

\subsection{Jenis data}

Data primer adalah data yang diperoleh atau dikumpulkan oleh peneliti secara langsung dari sumber datanya.Data primer disebut juga sebagai data asli atau data baru yang memiliki sifat up to date.Untuk mendapatkan data primer, peneliti harus mengumpulkannya secara langsung. Teknik yang dapat digunakan peneliti untuk mengumpulkan data primer antara lain observasi, wawancara, diskusi terfokus (focus grup discussion - FGD)dan penyebaran kuesioner.Metode pengumpulan data yang digunakan dalam penelitian ini adalah kuesioner.Selanjutnya kuesioner yang berisikan serangkain pertanyaan yang terkait dengan tujuan penelitian dan diisi oleh pemilik atau manajer perusahaan yang dianggap memahami operasional perusahaan. Dengan 
demikian sifat informasi yang diperoleh adalah persepsional dari responden yang menggambarkan deskripsi dari variable orientasi pasar, nilai inovasi, keunggulan bersaing dan kinerja unit usaha dan jasa berbasis syari'ah.Malang raya yang sesuai dengan kriteria sampel penelitian.

Data Sekunder adalah data yang diperoleh atau dikumpulkan peneliti dari berbagai sumber yang telah ada (peneliti sebagai tangan kedua).Data sekunder dapat diperoleh dari berbagai sumber seperti Biro Pusat Statistik (BPS), buku, laporan, jurnal, dan lain-lain.

\subsection{Metode Analisis Data}

Penelitian ini bertujuan untuk mencari hubungan linear prediktif antar variabel yaitu melalui pengujian hipotesis penelitian yang telah diajukan.Partial Least Square (PLS) merupakan pilihan yang tepat dalam penelitian ini yang bertujuan melakukan estimasi path model dengan menggunakan konstruk laten dengan multiple indicator. Model spesifikasi dalam PLS meliputi: outer model, inner model dan weight relation.

\section{PEMBAHASAN}

\subsection{Evaluasi Measurement (outer) Model}

Convergent Validity dari measurement model dengan indikator reflektif dapat dilihat dari nilai korelasi antara skor indikator dengan skor kontruksnya. Setiap Indikator dianggap mempunyai validitas yang baik jika memiliki nilai korelasi diatas 0.70

Tabel. 1 Outer Loadings (Mean, STDEV, T-Values)

\begin{tabular}{|c|c|c|c|c|c|}
\hline & $\begin{array}{l}\text { Original } \\
\text { Sample (O) }\end{array}$ & $\begin{array}{l}\text { Sample } \\
\text { Mean (M) }\end{array}$ & $\begin{array}{l}\text { Standard } \\
\text { Deviation } \\
\text { (STDEV) }\end{array}$ & $\begin{array}{l}\text { Standard } \\
\text { Error } \\
\text { (STERR) }\end{array}$ & $\begin{array}{l}\text { T Statistics } \\
(\mid \text { O/STERR } \mid)\end{array}$ \\
\hline $\mathrm{KB} 1<-\mathrm{KB}$ & 0.883974 & 0.883623 & 0.040491 & 0.040491 & 21.831442 \\
\hline $\mathrm{KB} 2<-\mathrm{KB}$ & 0.838826 & 0.838713 & 0.043637 & 0.043637 & 19.222815 \\
\hline KB3 <- KB & 0.809406 & 0.806068 & 0.062939 & 0.062939 & 12.860148 \\
\hline KP1 <- KP & 0.900797 & 0.898547 & 0.029669 & 0.029669 & 30.361849 \\
\hline KP2 <- KP & 0.855916 & 0.850811 & 0.050119 & 0.050119 & 17.077726 \\
\hline KP3 <- KP & 0.900959 & 0.895632 & 0.042508 & 0.042508 & 21.195160 \\
\hline NI1 <- NI & 0.853092 & 0.853133 & 0.049925 & 0.049925 & 17.087416 \\
\hline $\mathrm{NI} 2<-\mathrm{NI}$ & 0.937755 & 0.938614 & 0.024824 & 0.024824 & 37.776367 \\
\hline NI3 <- NI & 0.912592 & 0.909194 & 0.067897 & 0.067897 & 13.440800 \\
\hline OP1 <- OP & 0.953451 & 0.952769 & 0.017525 & 0.017525 & 54.404376 \\
\hline OP2 <- OP & 0.928736 & 0.925917 & 0.024758 & 0.024758 & 37.512426 \\
\hline OP3 <- OP & 0.931985 & 0.929455 & 0.019599 & 0.019599 & 47.553413 \\
\hline
\end{tabular}

Sumber: Data yang diolah (2017) 
Pada Tabel. 1 tampak bahwa masing masing indikator memiliki nilai korelasi melebihi 0.70. dengan demikian dapat dinyatakan bahwa indikator penelitian memenuhi unsur validitas yang baik. Untuk variabel orientasi pasar, indikator yang dominan adalah orientasi pada pelanggan (OP1). Dalam situasi bisnis yang sangat kompetitif, perusahaan harus sensitif pada apa yang diharapkan pelanggan. Untuk variabel nilai inovasi, indikator yang dominan adalah kemitraan dengan nasabah (NI2). Dalam proses transaksi ada kalanya nasabah dengan segala keterbatasannya akan berusaha untuk mendapatkan layanan yang sesuai dengan harapannya sehingga perusahaan harus bisa melakukan negosiasi dengan nasabah. Untuk variabel keunggulan bersaing indikator yang dominan adalah tingkat efektivitas implementasi strategi perusahaan (KB1). Keunggulan bersaing didapatkan manakala perusahaan berhasil menjalankan strategi bisnis secara efektif dibanding pesaing. Setiap perusahaan dengan karakteristik lingkungan internal maupun eksternal yang berbeda tentu memiliki bentuk bersaing yang berrbeda. Mereka yang unggul dalam persaingan adalah yang paling efektif menjalankan strateginya.

Uji measurement selain uji validitas kontruk adalah uji reliabilitas konstruk yang diukur dengan dua kriteria yaitu composite reliability dan cronbachalpha dari blok indikator yang mengukur konstruk. Konstruk dinyatakan reliabel jika nilai composite reliability maupun cronbach alpha diatas 0.70 .

Tabel. 2 menyajikan nilai composite reliability dan cronbach alpha.

\begin{tabular}{|l|l|l|}
\hline & Composite Reliability & \multicolumn{1}{|c|}{ Cronbachs Alpha } \\
\hline KB & 0.881761 & 0.799538 \\
\hline KP & 0.916413 & 0.863014 \\
\hline NI & 0.928828 & 0.884777 \\
\hline OP & 0.956544 & 0.931895 \\
\hline
\end{tabular}

Sumber: Data yang diolah (2017)

Nilai composite reliability maupun nilai cronbachalpha mempunyai nilai diatas 0.70 sehingga dapat dinyatakan bahwa konstruk memiliki reliabilitas yang tinggi.

\subsection{Pengujian Model Struktural (Inner Model)}

Pengujian terhadap model struktural dilakukan dengan melihat nilai $R$-Square yang merupakan uji goodness of fit model.

Tabel. 3 R-Square

\begin{tabular}{|l|l|}
\hline & R Square \\
\hline KB & 0.757731 \\
\hline KP & 0.898044 \\
\hline NI & 0.610180 \\
\hline \hline
\end{tabular}


Sumber: Data yang diolah (2017)

Nilai R Square menunjukkan angka yang relative besar diatas $60 \%$ yang dapat diartikan bahwa variabilitas konstruk dependent dapat dijelaskan oleh variablitas konstruk independen cukup besar. Ini berarti model memiliki goodness of fit yang baik dengan data. Gambar 1 berikut merupakan ringkasan uji measurement model.

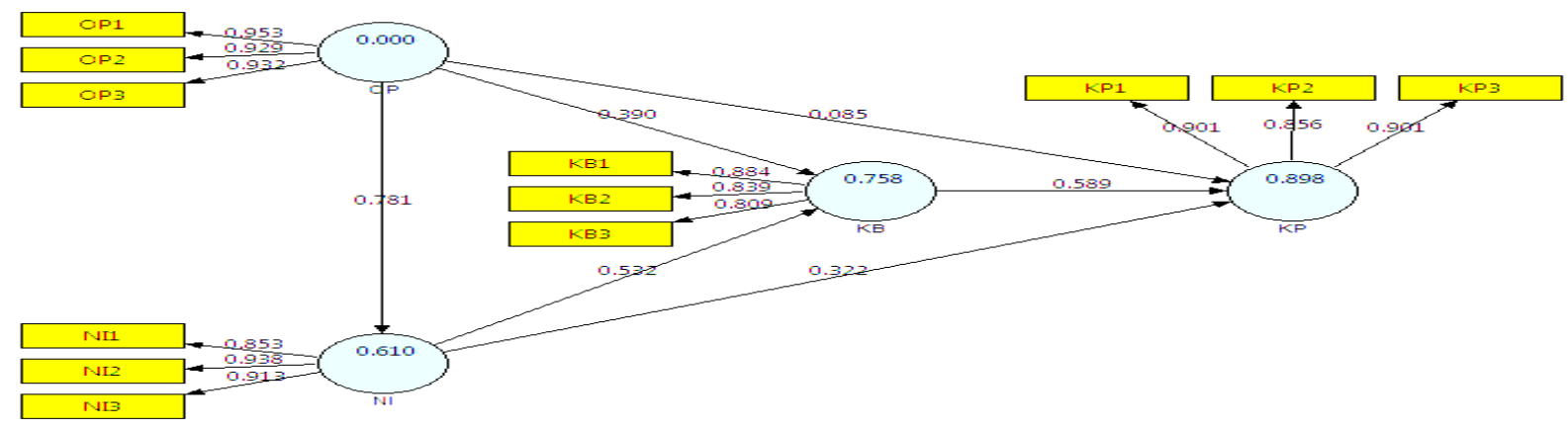

Gambar.2Measurement Model.Pengaruh Orientasi Pasar terhadap Nilai Inovasi, Keunggulan Bersaing dan Kinerja Unit Usaha dan Jasa Berbasis Syari'ah.

Uji berikutnya adalah melihat signifikansi pengaruh antar variabel dengan melihat nilai koefisien parameter dan nilai signifikansi t statistik. Tabel 4 menyajikan koefisien pada tiap jalur hipotesis.

Tabel. 4. Path Coefficients (Mean, STDEV, T-Values)

\begin{tabular}{|c|c|c|c|c|c|}
\hline & $\begin{array}{l}\text { Original } \\
\text { Sample (O) }\end{array}$ & $\begin{array}{l}\text { Sample } \\
\text { Mean (M) }\end{array}$ & $\begin{array}{l}\text { Standard Deviation } \\
\text { (STDEV) }\end{array}$ & \begin{tabular}{|l|} 
Standard \\
Error \\
$($ STERR) \\
\end{tabular} & $\begin{array}{l}\text { Tr } \\
(\mid \text { O/STERR } \mid)\end{array}$ \\
\hline OP -> NI & 0.781140 & 0.780986 & 0.052379 & 0.052379 & 14.913299 \\
\hline $\mathrm{OP}$-> KB & 0.389508 & 0.394977 & 0.114178 & 0.114178 & 3.411418 \\
\hline OP $->\mathrm{KP}$ & 0.085108 & 0.078727 & \begin{tabular}{|l|l|}
0.065990 \\
\end{tabular} & 0.065990 & 1.289716 \\
\hline $\mathrm{NI}$-> KB & 0.531556 & 0.526923 & 0.123226 & 0.123226 & 4.313684 \\
\hline NI $>$ KP & 0.322110 & 0.307299 & 0.098563 & 0.098563 & 3.268048 \\
\hline $\mathrm{KB} \rightarrow \mathrm{KP}$ & 0.588714 & 0.610449 & 0.108631 & 0.108631 & 5.419408 \\
\hline
\end{tabular}

Sumber: Data yang diolah (2017)

T tabel 2.004

Dari tabel 4 dapat disimpulkan bahwa hanya satu jalur yang mempunyai nillai t statistik (1.289) lebih besar dari t tabel (2.004) yaitu jalur pengaruh orientasi pasar terhadap kinerja unit usaha dan jasa berbasis syariah. Temuan ini sekaligus menolak hipotesis bahwa ada pengaruh signifikan orientasi pasar terhadap kinerja unit usaha dan jasa berbasis syariah $\left(\mathrm{H}_{3}\right)$.

\section{KESIMPULAN DAN SARAN}




\subsection{Kesimpulan}

Tujuan penelitian ini adalah untuk menguji apakah pangaruh antara orientasi pasar, nilai inovasi dan keunggulan bersaing terhadap kinerja unit usaha dan jasa berbasis syariah. Hasil pengujian secara statistik menunjukkan bahwa orientasi pasar mempunyai pengaruh signifikan terhadap nilai inovasi. Orientasi pasar dengan Keunggulan bersaing mempunyai pengaruh signifikan. Nilai inovasi dengan keunggulan bersaing mempunyai pengaruh signifikan. Orientasi pasar dengan kinerja unit usaha dan jasa berbasis syariah tidak mempunyai pengaruh signifikan. Penelitian ini membuktikan bahwa nilai inovasi dan keunggulan bersaing merupakan variabel intervening untuk menciptakan kinerja unit usaha dan jasa berbasis syariah. Adapun beberapa masalah yang perlu diperhatikan yaitu:

1. Implikasi Managerial

Perusahaan harus bisa membangun budaya orientasi pasar sebagai acuan menciptakan inovasi berkelanjutan. Konsekuensi bagi manajerial adalah setiap karyawan harus mempunyai perilaku berbagi pengatahuan. Perilaku ini diperlukan dalam rangka berbagi informasi yang diperlukan didalam merencanakan strategi perusahaan. Keunggulan bersaing bagi unit usaha dan jasa berbasis syariah dibangun dengan memperkuat faktor sumberdaya internal. Unit usaha dan jasa berbasis syariah perlu melakukan perberdaayaan kepada karyawan agar bertindak kreatif sebagai sumber inovasi. Kesempatan untuk belajar ataupun berbagai pelatihan dieperlukan untuk meningkatkan daya kreativitas.

2. Keterbatasan Penelitian

Secara metodologi terkait dengan sampel penelitian akan lebih baik jika jumlah observasi mencukupi dan representatif agar diperoleh karakteristik sampel yang mendekati populasi. Riset ini diakui mempunyai keterbatasan sampel yang hanya berjumlah 60 manajer unit usaha dan jasa yang berbais syariah sebagai responden. Keterbatasan lain adalah kinerja unit usaha dan jasa berbasis syariah yang diukur secara persepsional bisa menimbulkan bias dan kurang representatif, seharusnya digunakan ukuran yang lebih kuantitatif.

\section{Daftar Pustaka}

Akimova, Irina. 1999. "Development of Market Orientation and Competitiveness

Amabile, Teresa M. 1996. "Assesing The WorkEnvironment For Creativity".Academy of Management Journal. p.1154-1184

Arida, Dwi Harja A.S. 2016 Keputusan Nasabah Dalam Mengambil Produk Pembiayaan Pada Bank Syariah (Studi Kasus Pada Bank Syariah X Cabang Malang) Skripsi: Fakultas Ekonomi dan Bisnis Universitas Brawijaya Malang

Arfan, Abbas \& Saifullullah, Fakhruddin, 2016Implementasi prinsip bagi hasil dan manajemen risiko dalam produk-produk pembiayaan perbankan syariah di kota Malang. Jurnal Penelitian Sosial Keagamaan Inferensi Vol 10 no 1

Atuahene-Gima, K. 2001, 'Market Orientation and Innovation', in: Journal ofBusiness Research 35: 93-103. 
Bharadwaj, Sundar G, P.R.Varadarajan, \& Fahly, Jihn. 1993. "Sustainable Competitive Advantage in Service Industries: A Conceptual Model andResearch Propositions “.JournalofMarketing.Vol.57,Oktober,p.83-99. Burden, Rebecca \& Proctor, Tony. (2000). "Creating Sustainable Competitive Advantage Through Training".TeamPerformanceManagement An InternationalJournal.p.90-96. Cooper, Robert G. 2000. "Product Inovation and Technology Strategy".Journal Droge, Cornelia \& Shownee Vickrey. 1994. "Source and Outcomes of Competitive Advantage: An Explanory Study in The Furniture Industry". Decision Sciences.p.669-689. EdisiPertama, Cetakan Pertama,UMMPress, Malang.

Drucker, Peter F. 1985. "Inovation and Entrepreneurship": Practice and principle. Jurnal of London. Wiliam Heinemann.Research Technology Management.p.38-41.

Duffy, Dennis L, 1998, “Customer Loyality Strategiess", Jurnal of Consumer Marketing, Vol 15 no. 5, pp. 435-448.Erlangga. Jakarta.

Ferdinand, Augusty. 2000. "Manajemen Pemasaran: Sebuah Pendekatan Strategy". Jurnal Pemasaran. Research Paper Series.No.01 Program Magister Manajemen Universitas Graha Ilmu.Yogyakarta.

Hamel, Gary \& CK Prahalad.1991. "Competing For The Future”.Journal of Marketing.Boston: Harvard Business School Press.

Hamel, Gary.2000. "Leading the Revolution".Journal of Marketing.Boston: Harvard Business School Press.

Han, Jin. K, Namwoon Kim \& Rajendra K. Srivastava, 1998, "Market Orientation andOrganizational Performance: Is Innovation a Missing Link ?", Journal of Marketing,p.42-45.

Hunt, Shelby D \& Robert M Morgan, 1995, "The Comparative Advantage Theory of Competition", Journal of Marketing, p.1-15.

Jaworski, B.J., and A.K. Kohli. 1996. 'Market Orientation: Review, Refinement, and Roadmap', in: Journal ofMarket Focused Management 1: 119-135.

Jaworski, B.J.,and A. K. Kohli. 1993. 'Market Orientation: Antecedents and Consequences', in: Journal of Marketing57: 53-70.

Kim, W. Chan, and Renee Mauborgne. 2008." Blue Ocean Strategy: an Harvard business Scholl Publising Corporation" Decision Sciences p.31-38. Edisi Pertama. Cetakan Keduabelas, PT. Serambi Ilmu Semesta. 